\title{
Application of Bamboo Material in Modern Architecture
}

\author{
Mengting Yuan ${ }^{1, a}$, Xinqun Feng ${ }^{2, b}$ \\ 1Donghua University, No.1882 West Yan'an Road, Shanghai, China \\ 2Donghua University, No.1882 West Yan'an Road, Shanghai, China \\ aymt6921@163.com, bfengxinqun001@163.com
}

Keywords: bamboo; bamboo material; bamboo building; eco-friendly material

Abstract. In China, "bamboo culture" has a long history. As bamboo has the features of growing fast with high yield, as well as high intensity, rigidity, thermal stability, and other strengths in physical performance, the application of this material in architecture will help to promote the green and sustainable development of the industry. This paper gives a brief introduction of the new bamboo material and its processing technology, while comparing its mechanical properties. The application ways of bamboo material in building structure, building skins and building decoration are also briefly analyzed to look into the challenges in the development of bamboo material and provoke thinking.

\section{Introduction}

With the popularity of the concept of sustainable development, green buildings have become the main development direction of future architecture. As a kind of eco-friendly material, bamboo is featured by renewable, growing fast, economical, safe, durable, and so on. What's more, Chinese bamboo culture has been inheriting for several thousand years, promoting increasingly wide use of bamboo material. However, the application of bamboo material in architecture is somehow limited at present, which should be studied constantly.

\section{The idea and theory of bamboo material}

\section{Based on the inheritance of Chinese traditional bamboo culture}

For a long history, bamboo has been regarded as national spirit of China for symbolizing the virtue of humility, moral integrity, fidelity and filiality, which fits in with the Chinese traditional aesthetic taste and morality. The bamboo culture reflects a kind of natural and harmonious eastern philosophy, which has a subtle influence on the structure and design of architecture in the evolvement of history. The wide use of bamboo material in construction embodies an everlasting pursue of harmonious symbiotic relationship between the nature and human being, as well as the nature and architecture.

\section{Based on the guiding ideology of sustainable development}

Under the guiding ideology of sustainable development, green building is the main development direction of today's architecture. At present, the Chinese architectures are mainly using fossil energy, and the energy-saving buildings can only make limited contributions to energy saving and emission reduction. Developing new environmental protection materials is a direct and effective method. It is known from scientific data that, compared with other materials, bamboo can achieve "zero emissions". Using Bamboo material can reduce radiation and help saving forest resources; Besides, the good ventilation performance of bamboo buildings can save power. 
Table 1 Comparison of overall performance of main building materials [1]

\begin{tabular}{|c|c|c|c|c|}
\hline \multirow{2}{*}{ Performance index } & \multicolumn{4}{|c|}{ Types of materials } \\
\cline { 2 - 5 } & Bamboo & Wood (spruce) & Concrete & Steel \\
\hline Tensile strength & $35-300$ & 90 & $1.26-12.6$ & $250-350$ \\
\hline Compressive strength & $64-110$ & 43 & $12.6-126$ & $250-350$ \\
\hline Regenerative capacity & $80 \%-300 \%$ & $3 \%-6 \%$ & No & No \\
\hline Mature time & $7-9$ & $60-80$ & $/$ & $/$ \\
\hline Mature time after felling & 1 & $60-80$ & $/$ & Medium \\
\hline Construction pollution & Slight & Slight & Serious & Recyclable \\
\hline Waste treatment & $\begin{array}{c}\text { Easy for } \\
\text { degradation }\end{array}$ & $\begin{array}{c}\text { Easy for } \\
\text { degradation }\end{array}$ & $\begin{array}{c}\text { Construction } \\
\text { waste }\end{array}$ & \\
\hline
\end{tabular}

\section{Materials Chosen based on region and climate}

China is rich in bamboo resources. There are about 100 categories and more than 1200 species of bamboo in the world. And there are 39 categories and about 500 species in China, in which 16 categories and 200 species have been cultivated and used for their economic and ecological value. The bamboo is a high quality environmentally friendly material, and belongs to short cycle, renewable forest resource for its growth period of 3-5 years.

About 1/4 territory of China belongs to subtropical monsoon climate, in which the lives more than half of the population of China.

Subtropical climate is hot in summer with plenty of rain. The construction of Chinese folk houses are mainly based on local conditions. The Dai bamboo houses and stilted buildings in the south of the Qinling and the Huaihe River are typical cases of using bamboo.

\section{The Analysis of the characteristics of bamboo material}

\section{The structure of bamboo wood}

Bamboo wood, also known as bamboo stalk, refers to the trunk of bamboo after being felled and removing branches, consisting of bamboo joints and internodes, the shape of which is hollow cylinder. Bamboo joint includes stem ring, bamboo shoots shell and transverse wall. Bamboo vascular bundles are parallel to each other in the internodes of bamboo stalks, and the vascular bundles at bamboo joints are bent and crisscrossed, which makes the higher variability and non-uniformity in mechanical properties than that of wood. The bamboo joints can improve the compressive strength of bamboo stalks. The compression strength parallel to grain at bamboo joints is $8 \%$ higher than that in internodes, and the compression strength perpendicular to grain at bamboo joints is $45 \%$ higher than that in internodes [3].

\section{Mechanical Performance Advantages}

The mechanical properties of bamboo refer to its performance of resisting external forces, including tensile strength, compressive strength, static bending strength, shear resistance, shock resistance, as well as elastic modulus. The mechanical properties of bamboo closely related to its moisture content, bamboo stalk parts and the type of bamboo, thus, these factors should be fully considered when studying the bamboo [3]. Table 2 shows the main mechanical performance indications of common types of bamboo and wood. The data in the table shows that the tensile strength of bamboo is about 2 times that of the wood; the compressive strength of bamboo is approximately $20 \%$ higher than that of wood. 
Table 2 Comparison of Bamboo and Wood in Strength [3]

\begin{tabular}{|c|c|c|c|c|c|}
\hline \multirow{2}{*}{\multicolumn{2}{|c|}{ Types }} & \multicolumn{2}{|c|}{ Tensile strength } & \multicolumn{2}{|c|}{ Compressive strength } \\
\hline & & Intensity & Mean value & $\begin{array}{l}\text { Resistant to } \\
\text { compression }\end{array}$ & Mean value \\
\hline \multirow{4}{*}{ Bamboo } & Moso bamboo & 194.8 & \multirow{4}{*}{213.9} & 64.0 & \multirow{4}{*}{48.8} \\
\hline & Phyllostachys & 283.3 & & 54.0 & \\
\hline & Henon bamboo & 182.1 & & 35.9 & \\
\hline & $\begin{array}{c}\text { Dendrocalamus } \\
\text { latiflorus }\end{array}$ & 195.1 & & 41.1 & \\
\hline \multirow{4}{*}{ Wood } & Fir wood & 77.2 & \multirow{4}{*}{100.8} & 40.6 & \multirow{4}{*}{42.9} \\
\hline & Korean pine & 98.1 & & 32.8 & \\
\hline & German oak & 143.2 & & 57.7 & \\
\hline & Sassafrases & 110.8 & & 46.5 & \\
\hline
\end{tabular}

\section{Advantage of Thermal Stability}

Bamboo has a good heat preservation and heat insulation performance, with relatively low thermal conductivity of about $0.30 \mathrm{w} / \mathrm{m} \cdot \mathrm{k}$ or so [4]. With the same thickness, the insulation value of bamboo is 16 times higher than that of standard concrete, and 400 times higher than that of steel [4]. In addition, the annual average humidity of bamboo architecture ranges from $60 \%$ to $80 \%$, which is most close to the relative humidity index of optimum living condition $-60 \%$ or so[4]. Thus, bamboo architecture is with low energy consumption and without the inherent problems of concrete and steel structure of thermal bridge and the resulting problem of moisture condensing on cold surfaces.

\section{New Common Types of Bamboo wood}

\section{Parallel Bamboo Strand Lumber}

Parallel bamboo strand lumber is a kind of structural material with high density, intensity and rigidity. It is of close agglutination and high stability and without crack, dehiscence, and deformation, the composite structure of which is similar to recombinant wood. It is an artificial plate or other type composite bamboo material which is processed from bamboo strips of a certain specifications through drying, crushing, wire drawing, gum dipping, tissue embryon, hot pressing and agglutination. It has been applied in the architectural material area with its physical performance of high longitudinal strength, processing performance and material utilization rate.

\section{Bamboo Plywood}

The types of bamboo plywood mainly include: bamboo-curtain plywood, bamboo woven plywood, woven mat and curtain plybamboo, bamboo plywood, bamboo particle board, etc. During the process of bamboo plywood, semicircle bamboo is softened and chopped tube into flat bamboo strips with certain thickness and width. By heating, increasing moisture and improving surface condition to improve plasticity and reduce reverse bending stress, the strips are clued and compressed into plate with high strength and good rigidity. With the characteristics of waterproof, moisture proof, anticorrosion and alkali prevention, it is of 100 times of ordinary wood in hardness, and 1.5-2 times of wood in tensile strength.

\section{Bamboo Laminated Material}

Currently, bamboo laminated material is an appropriate bamboo wood. It is a type of plate or square-edged timber made by sticking thin bamboo strips or thin bamboo strip curtains together 
through concurrent pavement, hot pressing or cold pressing, which has good water resistance, weather resistance and mechanical properties, and can be used as load-carrying components. China has a long history of producing bamboo laminated material with mature and stable technologies, and the production cost is lower than that of bamboo integrated timber. Besides, the high longitudinal strength and rigidity can help meeting the demand of modern construction industry for structural materials [5].

Table 3 Comparison of Commonly Used Bamboo Engineering Materials in Mechanical Properties [5]

\begin{tabular}{|c|c|c|c|c|}
\hline Material & Density g/cm3 & $\begin{array}{c}\text { Static bending } \\
\text { strength/MPa }\end{array}$ & $\begin{array}{c}\text { Elastic } \\
\text { modulus/GPa }\end{array}$ & $\begin{array}{c}\text { Compression strength } \\
\text { parallel to grain/MPa }\end{array}$ \\
\hline $\begin{array}{c}\text { Parallel bamboo } \\
\text { strand lumber }\end{array}$ & 1.10 & 172 & 14.3 & 117.5 \\
\hline $\begin{array}{c}\text { Bamboo-curtain } \\
\text { plywood }\end{array}$ & $0.85-0.90$ & 110 & 10 & $/$ \\
\hline $\begin{array}{c}\text { Bamboo laminated } \\
\text { material }\end{array}$ & 0.95 & 130 & 11 & 58.3 \\
\hline Bamboo material & 0.789 & 150 & $12-20$ & $64-70$ \\
\hline
\end{tabular}

\section{Common Application of Bamboo materials in Architecture}

\section{Bamboo Materials Used in Construction Structure}

In bamboo architecture, bamboo, as the main architectural structure, plays the role of load holding of buildings. Bamboo has strong adaptability in thickness and strength and can make different combination adjustment accordantly based on the architectural structure to satisfy the requirement of different structural performance. On the other hand, the technical requirements of bamboo buildings are relatively low and can easily be integrated into local architectural structures, for example, the integration of bamboo with soil, concrete, and glue, etc, can help increasing the structural strength.

In modern bamboo architecture, the key technology of bamboo architecture lies in the junction point between primary structural elements bearing tension and stress. The stiffness, strength and stability of nodes mainly are mainly based on the joint strength between structure components of the building. Therefore, the increasing improvement of connection structure has brought more contributions to the diversification of bamboo architecture. 
Table 4 Analysis of Connection Modes of Original Bamboo

\begin{tabular}{|c|c|c|c|c|}
\hline $\begin{array}{l}\text { Connection } \\
\text { diagram }\end{array}$ & $\begin{array}{l}\text { Connection } \\
\text { mode }\end{array}$ & $\begin{array}{l}\text { Original } \\
\text { connection } \\
\text { part }\end{array}$ & Advantages & Disadvantages \\
\hline & Bundled node & $\begin{array}{l}\text { Rattan, coir } \\
\text { rope }\end{array}$ & $\begin{array}{l}\text { Simple in } \\
\text { technology, low in } \\
\text { cost, easy to } \\
\text { disassemble and } \\
\text { reorganize }\end{array}$ & $\begin{array}{l}\text { Coir rope is easy to } \\
\text { slack, break strand } \\
\text { and decay; the } \\
\text { stiffness of node is } \\
\text { insufficient }\end{array}$ \\
\hline & $\begin{array}{l}\text { Column-and-ti } \\
\text { e node }\end{array}$ & $\begin{array}{l}\text { Bamboo } \\
\text { ontology }\end{array}$ & $\begin{array}{l}\text { Good extensibility, } \\
\text { good economy }\end{array}$ & $\begin{array}{c}\text { Damage and weaken } \\
\text { the bamboo } \\
\text { structure; bear } \\
\text { vertical load } \\
\text { bamboo, splitting } \\
\text { phenomenon is } \\
\text { common }\end{array}$ \\
\hline & $\begin{array}{l}\text { Screw style } \\
\text { node } \\
\text { (strengthened } \\
\text { by cement } \\
\text { mortar } \\
\text { infusion) }\end{array}$ & $\begin{array}{l}\text { Screws, metal } \\
\text { construction, } \\
\text { cement mortar }\end{array}$ & $\begin{array}{c}\text { Bamboo stem is easy } \\
\text { to craze If connected } \\
\text { directly by screw, } \\
\text { pour into cement } \\
\text { mortar to enhance } \\
\text { the rigidity and } \\
\text { stability of nodes }\end{array}$ & $\begin{array}{l}\text { The holes drilled in } \\
\text { bamboo are small, so } \\
\text { cement mortar is } \\
\text { difficult to fill up; } \\
\text { the compactness is } \\
\text { hard to guarantee }\end{array}$ \\
\hline & $\begin{array}{c}\text { Steel members } \\
\text { and nodes of } \\
\text { steel plate } \\
\text { style }\end{array}$ & $\begin{array}{c}\text { Bolt, steel } \\
\text { hooks, snap } \\
\text { joint, metal } \\
\text { hoop, } \\
\text { high-strength } \\
\text { bolt with long } \\
\quad \text { staff }\end{array}$ & $\begin{array}{l}\text { Good durability; } \\
\text { even and reliable } \\
\text { transmission of } \\
\text { force; components } \\
\text { of node is easy to } \\
\text { disassemble, } \\
\text { recyclable }\end{array}$ & $\begin{array}{c}\text { The specifications of } \\
\text { original bamboo are } \\
\text { different, the node } \\
\text { plates are difficult } \\
\text { for industrial mass } \\
\text { production; the cost } \\
\text { is comparatively } \\
\text { high }\end{array}$ \\
\hline
\end{tabular}

\section{Bamboo Materials Used in Building "Skin"}

The outwall of building can be called "Skin", which can reflect the culture of the building. The diversity in bamboo use and its integration with other materials provides more opportunities to the diversification of building "skin" and the improvement of architectural aesthetics. Typically, the use of bamboo as building skins can be divided into three types:

(1) Single skin: A "bamboo skin" formed by only one material through various combinations, which is a relatively low level application of one kind of bamboo material in building skins. It is of simple production technology with low cost and good ventilation and sunlight prevention. Besides, it is helpful for keeping the architectural features with local architectures, however, it has shortcomings as poor lighting conditions and privacy. Therefore, it is usually used in exterior space and the enclosure of less important space.

(2) Multilayer skin: Juxtaposed and composed by two or more materials, which is a typical design method of using complementation of material properties, and can effectively overcome defects of single bamboo material. The juxtaposition of bamboo and glass is a very common 
combination form. The bamboo can filter outside inference (such as sunlight, the line of sight), and glass can block the sound and heat that bamboo cannot filter. The exchange between indoor and outdoor environment occurs from the open and close of the bamboo curtain, creating a breathable skin.

(3) Composite skin: Created by blending two or more materials, which breakthroughs their inhere properties and creates a third type of skin. In general, new skin incorporates the advantages of composite materials, for example, the composition of bamboo and rammed earth wall can both effectively reduce the weight of rammed earth wall and enhance the force bearing capability along the radial direction of bamboo.

\section{Bamboo Materials Used in Building Decoration}

Building decoration can be divided into architectural interior and exterior decoration.

Building interior decoration should fully considerate the natural characteristics of bamboo materials. The surface of bamboo materials is smooth, lightweight and flexible, with natural and gentle color, clear and beautiful texture. Bamboo decoration should make full use of the sense of reality, color, surface gloss and texture to reflect the nature of bamboo materials. The main decoration colors of bamboo materials include bamboo green, tabasheer and carbonization. In addition, bamboo can easily be bent, making it an ideal material for manufacturing all kinds of beautiful furniture.

Besides building skins, external decoration of buildings also includes virescence surrounding the building. The greening effect of bamboo on buildings can present in many forms, which can be classified into three main categories: clump, row, and tract. Bamboo grove in clump shape is concise and clear, pure and fresh, which is suitable for ornament and decoration to improve the taste of a building; bamboo grove in row shape is usually used in boundary space. Besides the role of decoration, it also has the function of blocking and shielding; to foil the environmental atmosphere, bamboo grove in tracts can usually be seen in an open area.

\section{The Challenges Faced by the Development of Bamboo Materials}

\section{Pay Attention to Both Development and Protection}

China has Bamboo abundant bamboo resources, and there are more bamboo resources with better performances worth exploring. In exploring bamboo resources, we should also pay attention to the protection work. To protect the resources, the first is to protect bamboo forest, reduce excessive deforestation, improve the yield per unit area through scientific means, and set up various types of bamboo grove bases, etc.

\section{Strengthen the Interdisciplinary Collaboration of Bamboo Materials}

It is necessary for personnel engaged in the research of bamboo materials to strengthen interdisciplinary collaboration with experts in other fields. To boost the greater contributions of bamboo materials to the field of construction, it is necessary to expand the knowledge system of bamboo materials from forestry to the field of engineering. At present, the interdisciplinary research of bamboo material and other material are relatively insufficient. In the future, deep exploration in the fusion of material properties should be conducted.

\section{Develop Bamboo building Related International Standards to Guide the Development of This industry}

At present, most bamboo buildings in the world are built without specific standards, and most products lack of generally accepted international standards. In recent years, INBAR and ISO have worked closely to develop bamboo building-related standards and specifications, which will be conducive to the standard, design and promotion in bamboo architecture industry ${ }^{[2]}$. The security 
and durability of bamboo buildings can only be improved when the relevant laws, regulations and standards have been increasingly improved, and the public recognition for bamboo architecture could be therefore enhanced.

\section{Conclusions}

Bamboo materials will face a new development opportunity with the formation of low carbon environmental protection idea and green building concept. It will greatly promote the development of construction industry and bamboo materials if we give full play to the characteristics and advantages of bamboo materials, strengthen cross-industry studies on bamboo materials, and explore actively the possibilities of bamboo materials in building structure, building skins, and indoor and outdoor decoration of buildings.

\section{References}

[1] Chen Xiaoyang. Study on Modern Buildings with Bamboo Structure [J].Architecture \& Culture, 2010, 07:108-109

[2] Zhao Fang, Xu Zhengdong, Zhang yazhuo, Zhang Shuangbao, Wang Yongbo. Prospect on the Application of Bamboo Structural Materials in Construction [J]. Construction Science and Technology, 2012, 03:47-49

[3] Liu Jing, Zhang Jialiang, Guo Jun, Li Yushun. Development of Modern Bamboo Structures [J]. Forest Engineering, 2013, 12:126-130 + 134.

[4] Zhu Jianxin, Cheng Suling. Discussion on Ecological Quality of Buildings with Bamboo Structure [J]. Building Science, 2005, 92:92-94.

[5] Zhu Yi, Chen yu, Chen Keyi. Basic Properties and Application Status of New Bamboo Materials for Construction [J]. Huazhong Architecture, 2014, 10:56-59. 